\title{
Administration of Supplemental L-Tyrosine with Phenelzine: A Clinical Literature Review [Expression of Concern]
}

Hinz M, Stein A, Cole T, Ryan P. Clin Pharmacol Adv Appl. 2014;6:107-110.

The Editor-in-Chief and Publisher of Clinical Pharmacology: Advances and Applications wish to issue an Expression of Concern for the published article.

Concerns have been raised regarding the alleged undisclosed competing interests of some of the authors and alleged excessive self-citation for the published article. Clinical Pharmacology: Advances and Applications would like to alert readers of this while our investigation is still ongoing and we will provide an update following the conclusion of our investigation.

The authors have been informed of these concerns and of our investigation.

\section{Publish your work in this journal}

Clinical Pharmacology: Advances and Applications is an international, peer-reviewed, open access journal publishing original research, reports, reviews and commentaries on all areas of drug experience in humans. The manuscript management system is completely online and includes a very quick and fair peer-review system, which is all easy to use. Visit http://www.dovepress.com/testimonials.php to read real quotes from published authors. 